\title{
Pengembangan Aplikasi Lelang Karet Berbasis Mobile Sebagai Pendukung Akses Informasi Lelang
}

\author{
Andri $^{1}$, Suyanto \\ ${ }^{1,2}$ Program Studi Sistem Informasi, Universitas Bina Darma \\ email: andri@binadarma.ac.id ${ }^{1}$, email: suyanto@binadarma.ac.id ${ }^{2}$
}

(Received: 14 Oktober 2020 / Accepted: 24 November 2020 / Published Online: 20 Desember)

\begin{abstract}
Abstrak
Koperasi lelang karet merupakan koperasi dengan fungsi utama untuk melakukan lelang hasil pertanian karet bagi masyarakat anggota koperasi. Saat ini diantara permasalahan yang muncul dalam proses lelang yaitu: pertama, peserta lelang yang harus mendatangi tempat lelang walau hanya untuk memberikan tawaran harga. Kedua, proses administrasi lelang menimbulkan redudansi data peserta yang disebabkan harus mengisi formulir setiap mengikuti lelang. dari kedua permasalahan tersebut maka pada penelitian ini dilakukan pengembangan aplikasi sebagai media lelang bagi pihak terkait. Aplikasi yang dikembangkan adalah aplikasi berbasis mobile agar dapat diakses dengan mudah semua pihak. Metode yang digunakan dalam proses pengembangan yaitu metode adaptive software development dengan tiga tahapan utama speculation, collaboration, dan learning dengan teknik pengujian aplikasi black box testing. Hasil penelitian berupa aplikasi dengan fitur utama melakukan proses lelang dari sisi koperasi, dan peserta lelang dapat memberikan tawaran harga melalui aplikasi. Aplikasi yang dikembangkan juga berfungsi dengan baik sesuai dengan fitur yang ada dibuktikan dengan hasil pengujian aplikasi menggunakan teknik black box sehingga dapat membantu proses lelang karet bagi pihak terkait.
\end{abstract}

Kata kunci: Adaptive, Aplikasi, Black Box, Koperasi, Software

\begin{abstract}
Rubber auction cooperatives are cooperatives whose main function is to auction rubber agricultural products for these member communities. Currently, among the problems that exist in the auction process, namely: first, auction entrants must come to the auction site even if only to bid a price. Second, the auction administration process has redundant of entrant data due to having to fill out a form every time they participate in the auction. From these two problems, this research will conduct application development as an auction medium for related parties. The application developed is a mobile-based application so that it can be accessed easily by all parties. The method used in the development process is the adaptive software-development method with three major stages of speculation, collaboration, and learning which was tested using black box testing. The Research Results are an application with the main feature of conducting the auction process from the cooperative's side, and auction participants can bid prices through the application. The application developed also functions properly in accordance with existing features as evidenced by the results of application testing using the black box technique so that it can help the rubber auction process for related parties.
\end{abstract}

Keywords: Adaptive, Application, Black Box, Cooperative, Software

\section{PENDAHULUAN}

Teknologi informasi dan komunikasi (TIK) saat ini merupakan tulang punggung dalam menggerakkan roda bisnis atau proses bisnis dalam sebuah instansi. Penggunaan TIK disebabkan banyak faktor diantaranya adalah membuat pekerjaan lebih cepat dan akurat. Selain itu juga penggunaan TIK dapat membuat sebuah proses menjadi transparan atau jelas 
bagi semua pihak. Penggunaan TIK sendiri saat ini dapat dikatakan telah menyentuh di semua lini kehidupan baik di pemerintahan, industri, perusahaan atau bahkan di lingkungan usaha kecil dan menengah (Surjono, 2013). Jika ditinjau kembali dengan adanya TIK semua pihak dapat terbantukan, kondisi tersebut disebabkan TIK tidak terbatas ruang dan waktu serta membuat semua orang dalam posisi yang sama. Salah satu penggunaan TIK saat ini dibuktikan banyaknya aplikasi yang disediakan untuk mendistribusikan informasi atau aplikasi untuk menjalankan roda bisnis baik yang bersifat individu ataupun masal (Basry \& Sari, 2018).

Salah satu jenis usaha yang terdampak dari penggunaan TIK adalah koperasi, dimana saat ini telah banyak penggunaan TIK jenis aplikasi yang telah diterapkan di koperasi. Kondisi tersebut dapat dilihat dari aplikasi simpan pinjam yang telah banyak digunakan oleh koperasi (Rahma, 2018). Salah satu koperasi yang ada yaitu Koperasi Maju Bersama, koperasi ini dibuat untuk meningkatkan perekonomian masyarakat desa khusus untuk petani karet. Sesuai dengan tujuan utamanya koperasi ini bertugas untuk melakukan penjualan karet dengan cara melakukan lelang karet hasil petani kepada pihak pembeli atau sering dikenal dengan lelang bahan olahan karet (bokar). Bokar merupakan sistem lelang yang dilakukan pada Koperasi Maju Bersama dimana peserta lelang sendiri merupakan pihak pabrik yang melakukan pengolahan karet itu sendiri.

Dari proses lelang atau yang kenal dengan Bokar tersebut tentunya terdapat beberapa kendala terutama dalam proses lelang. Dimana proses lelang dilakukan dengan cara konvensional atau peserta lelang harus mendatangi langsung tempat lelang dan melakukan penawaran secara langsung. Selain itu juga terdapat proses administrasi yang berulang seperti pengisian data peserta lelang dan penawaran lelang kepada pihak pabrik. Kendala lain juga yang dihadapi oleh pihak tempat pelayanan koperasi (TPK) seperti informasi data jumlah karet yang akan dilelang karena anggota koperasi sendiri merupakan masyarakat sekitar koperasi yang terlambat memberikan informasi kepada petugas. Dengan kondisi tersebut tentunya dapat dilakukan atau diatasi dengan memanfaatkan TIK terutama aplikasi. Dimana aplikasi tersebut dapat dijangkau oleh pihak terkait baik itu pihak koperasi, petani ataupun pabrik perserta lelang itu sendiri sehingga proses lelang dapat dilakukan lebih efekti dan transparan.

Melihat kondisi dan permalahan yang ada maka perlu dibuat mekanisme proses lelang dengan menggunakan TIK tersebut. Salah satu cara yang paling mungkin dilakukan yaitu dengan cara membuat aplikasi berbasis mobile. Penggunaan aplikasi berbasis mobile sendiri disebabkan sebagian besar penduduk saat ini telah menggunakan perangkat mobile baik untuk komunikasi ataupun mencari informasi di internet (Ependi et al., 2020). Dengan demikian aplikasi yang dihasilkan dapat dimanfaatkan oleh pihak terkait dalam proses melakukan lelang. Untuk mendapatkan aplikasi yang tepat dalam melakukan proses lelang maka diperlukan metode pembuatan atau pengembangan aplikasi. Terdapat berbagai macam metode pengembangan diantaranya adalah Adatipve Software Development (ASD). Metode ASD ini merupakan metode turnan dari agile development. Dimana dalam proses pengembangan metode ASD dimulai dari penentuan kebutuhan namun dapat dilakukan perubahan ketika proses implementasi pengembangan. Secara garis besar proses pengembangan ASD terdiri tiga fase utama yaitu "speculation, collaboration, dan learning" (Wulan, 2016). ASD juga mengedepan kepuasan pelanggan sehingga dalam proses pengembangan selalu beradaptasi terhadap kebutuhan pelanggan (Elvaricha, 2019).

Kajian terkait dengan pengembangan aplikasi lelang ini telah dilakukan dengan topik yang berbeda diantaranya adalah (1) aplikasi lelang untuk barang jaminan, dimana pada penelitian ini mekanisme lelang yang dibuat dari perusahaan dan peserta lelang. selain itu juga objek yang menjadi bahan lelang merupakan barang jaminan (Nopita, 2018). (2) Implemenasi onesignal dalam proses pengembangan aplikasi lelang ikan. Dimana dalam 
penelitian ini onesignal digunakan sebagai jembatan dalam melakukan noifikasi kepada pihak terkait dalam proses lelang (Nuraminudin, 2020). (3) aplikasi lelang barang pegadaian, dimana pada penelitian ini dikembangan aplikasi lelang barang jaminan yang ada pada Pegadaian dengan sistem lelang online berbasis web (Sasmita \& Jasa, 2011). Melihat dari ketiga jenis aplikasi yang dikembangkan belum ada aplikasi yang dikhususkan bagi produk pertanian seperti karet. Selain itu juga jika melihat proses bisnis pada aplikasi sangatla berbeda terutama pada produk yang akan dilakukan lelang itu sendiri.

Berdasarkan penelitian yang telah dilakukan dimana proses pengembangan aplikasi dan objek lelang yang menjadi tolak ukur serta proses bisnis yang berbeda maka pada penelitian ini dilakukan pengembangan aplikasi lelang karet dengan menerapkan Adatipve Software Development (ASD) dalam proses pengembangan. Aplikasi yang dikembangkan dibuat dengan flatform berbasis mobile dengan sistem operasi android baik untuk pengguna koperasi mapun pihak peserta lelang atau pabrik. Dengan adanya aplikasi yang dihasilkan diharapkan dapat memberikan alternatif solusi yang dihadapi terutama dalam proses lelang karet. Selain itu juga dengan adanya aplikasi ini dapat meningkatkan akses dan transparansi bagi pihak terkait baik itu pihak koperasi, petani dan juga pabrik yang memberikan penawaran.

\section{METODE}

Penelitian adaptive software development (ASD) sebagai model pengembangan aplikasi lelang karet ini menggunakan metode penelitian deskriptif kualitatif. Metode penelitian deskriptif ini merupakan metode penelitian yang dapat digunakan untuk menjelaskan fenomena dan kejadian dari sebuah keadaan sebuah objek yang dilihat dari sudut pandang peneliti (Suyanto \& Andri, 2020). Metode deskriptif juga merupakan metode yang mampu menjelaskan fakta yang terjadi terhadap objek penelitian yang dilihat dari sudut pandang peneliti (Fatmasari \& Sauda, 2020). Untuk itu metode ini juga sangat tepat digunakan mengingat penelitian yang dilakukan merupakan fakta dan kejadian dalam proses pengembagnan aplikasi lelang karet. Selain dari metode penelitian dalam penelitian ini juga digunakan metode pengembangan adaptive software development (ASD). Metode ini digunakan untuk menjelaskan proses pengembangan dari aplikasi lelang karet. Proses pengembangan adaptive software development (ASD) ini sendiri seperti yang diperlihatkan pada Gambar 1 (Fatoni \& Dwi, 2016).

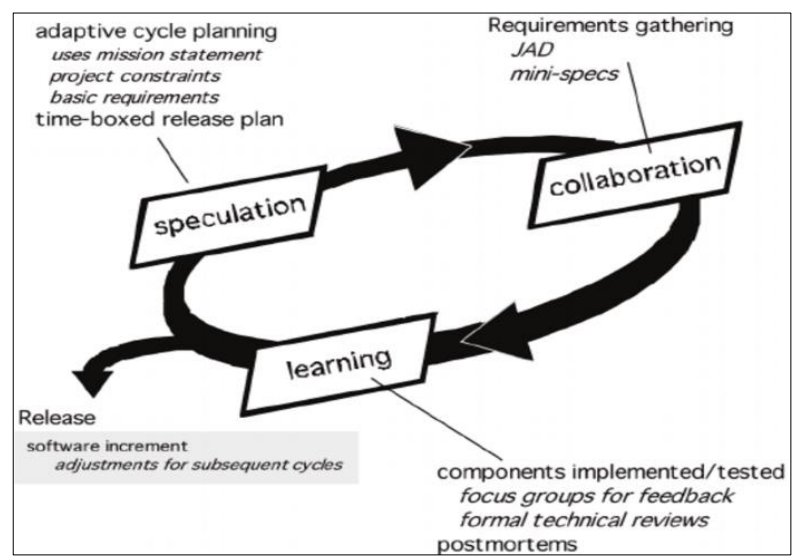

Gambar 1. Proses adaptive software development (ASD)

Berdasarkan dari gambar 1 maka dapat dijelaskan proses untuk masing-masing tahapan pengembangan terutama terkait dengan pengembangan aplikasi lelang karet sebagai berikut yaitu (Sagala, 2014): (1) Speculation, merupakan tahapan yang digunakan untuk memalkukan atau mempelajari dari visi dan misi. Kemudian pada tahapan ini juga dilakukan pengumpulan atau penggalian kebutuhan aplikasi yang akan dikembangkan. Kebutuhan aplikasi yang telah 
teridentifikasi digambarkan dalam bentuk software specification berupa notasi diagram unified modeling language (UML). (2) Collaboration, tahapan ini adalah tadapan dimana dilakukan pengumpulan tim baik dari sisi pengembang maupun dari sisi pihak koperasi. Setelah tim terkumpul dengan baik maka selanjutnya dilakukan pengembangan aplikasi lelang. Dalam penelitian ini dilakukan pengembangan aplikasi berbasis berbasis mobile untuk pihak terkait (peserta lelang). Hasil pengembangan akan dijelaskan kepada pihak terkait dan dilakukan perbaikan jika diperlukan. (3) Learning, tahapan ini adalah tahapan dimana dilakukan pengujian aplikasi yang telah selesai dibuat. Selanjutnya dilakukan perbaikan jika terdapat perubahan atau kesalahan. Dalam penelitian proses pengujian aplikasi dilakukan menggunakan pendekatan black box. Dimana proses pengujian ini mengedepankan masukkan dan keluaran dari aplikasi (Nugroho, 2018).

\section{HASIL DAN PEMBAHASAN \\ Hasil Penelitian}

Sesuai dengan prosedur penelitian dan langkah-langkah pengembangan aplikasi lelang karet dengan menggunakan adaptive software development (ASD). Maka hasil penelitian berupa aplikasi lelang karet. Penelitian ini dimulai dari identifikasi kebutuhan, pengembangan aplikasi dan pengujian aplikasi. Dari proses pengembangan seperti yang diperlihatkan pada Gambar 1 maka dapat dijelaskan bahwa dalam proses identifikasi kebutuhkan digambarkan dalam bentuk unified modelling language (UML), proses pengembangan dilakukan menggunakan flatform android dan pengujian dilakukan dengan pendekatan black box testing. Beriktu dapat dijelaskan proses pengembangan tesebut.

Untuk menggambarkan kebutuhan atau identifikasi kebutuhan aplikasi yang dikembangkan maka digunakan dua diagram yaitu use case diagram dan activity diagram. Dua jenis diagram tersebut merupakan jenis diagram yang ada pada unified modelling language (UML). UML merupakan jenis pemodelan yang mampu menyederhanakan dalam pemodelan informasi aplikasi yang sedang dikembangkan. Kemampuan UML yang lainnya yaitu dapat dijadikan tolak ukur dan akurat dalam proses pengembangan bagi pengembang (Andri \& Suyanto, 2020). Dalam penelitian ini untuk menggambarkan kebutuhan aplikasi digunakan dua jenis diagram yaitu behaviour diagram yang digambarkan dengan use case diagram dan interaction diagram yang digambarkan dalam bentuk activity diagram. Gambar 2 merupakan use case diagram dari aplikasi yang dikembangkan. Use case diagram sendiri merupakan diagram yang memiliki kemampuan untuk memperlihatkan bagaimana tingkah laku dari aplikasi sesuai dengan actor dari aplikasi (Tujni \& Hutrianto, 2020).

Seperti yang diperlihatkan pada Gambar 2 dapat dijelaskan bahwa terdapat tiga actor utama pada aplikasi yang terdiri dari peserta lelang, TPK dan admin koperasi. Masing masing actor harus melakukan login ketika ingin melakukan interaksi pada aplikasi. Jenis aktor peserta merupakan aktor yang akan mengikuti lelang atau pihak pabrik. Sedangkan TPK merupakan petugas koperasi yang memberikan informasi lelang kepada pihak pabrik, juga yang mendapatkan informasi jumlah karet yang akan dilakukan lelang dari petani. Aktor admin merupakan actor admin dari aplikasi.

Selain behaviour diagram yang digambarkan dalam bentuk use case diagram maka selanjutnya digambarkan pula kebutuhan aplikasi dalam bentuk interaction diagram. Interaction diagram adalah jenis diagram yang menggambarkan antara aktor pada aplikasi dengan objek yang ada pada aplikasi ketika berinteraksi (Ependi, 2018). Gambar 3 merupakan interaction diagram yang digambarkan menggunakan activity diagram. Jika ditinjau "Activity diagram sendiri merupakan diagram mampu untuk menggambarkan dan menampilkan prosedur logika apliasi dan proses bisnis dalam sebuah aplikasi sesuaid dengan jenis pengguna yang berinterkasi" (Hayat et al., 2015). Seperti yang diperlihatkan pada gambar 3 merupakan salah satu activity diagram dari aplikasi lelang karet. Dimana dimulai 
dari membuka aplikasi, menampilkan dashboard aplikasi, memili barang lelang, menampilkan deskripsi lelang, melakukan penawaran dan selanjutnya melakukan proses data.

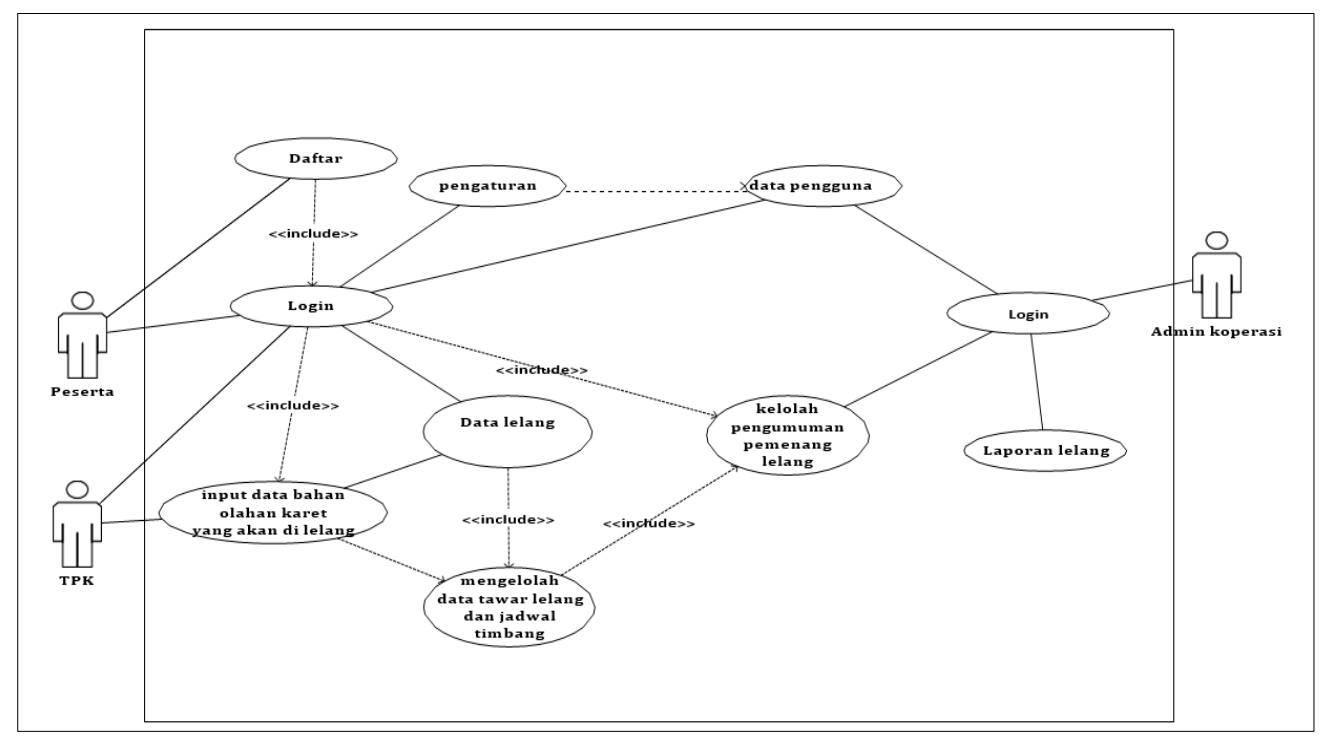

Gambar 2. Use Case Diagram Aplikasi

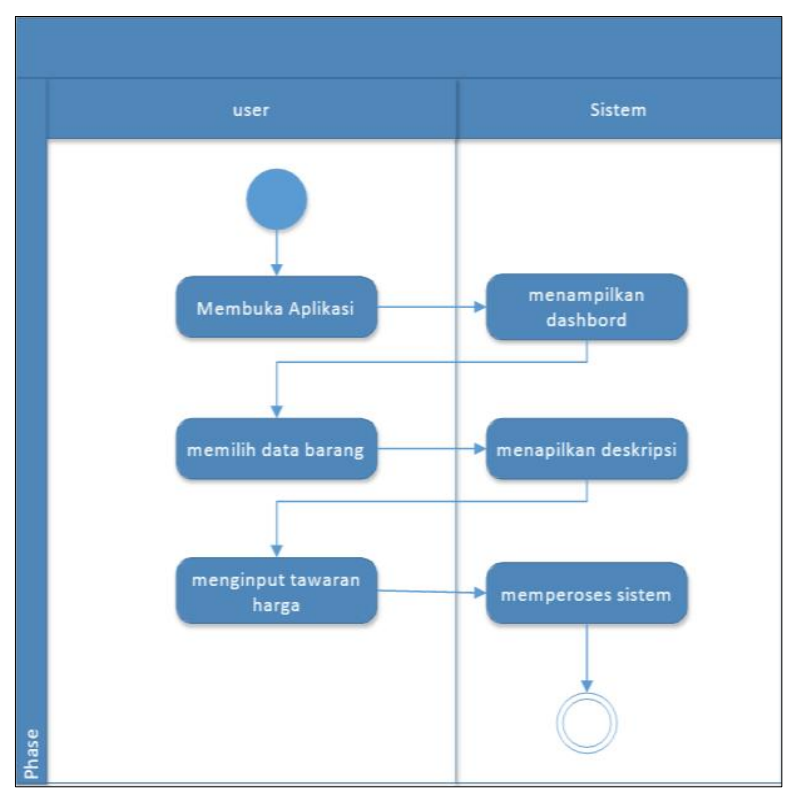

Gambar 3. Activity Diagram Peserta Lelang

Setelah proses pemodelan selesai dilakukan maka tahapan berikutnya yaitu melakukan proses pengembangan atau melakukan collaboration. Pada proses ini dilakukan pengembangan aplikasi lelang karet dengan mengikuti hasil pemodelan yang telah dilakukan. Gamabr 4 merupakan hasil pengembangan aplikasi. Seperti yang diperlihatkan pada Gambar 4 merupakan tampilan awal ketika aplikasi pertama kali dibuka. Dimana untuk mengakses menu atau aktivitas pada aplikasi maka pengguna diharuskan melakukan login denan memasukkan email sebagai username dan password. Namun jika pengguna belum memiliki akun maka diharuskan untuk melakukan registrasi dengan cara klik daftar akun. Ketika pengguna melakukan registrasi maka cukup memasukkan nama, email dan password seperti yang diperlihatkan pada gambar 4. 


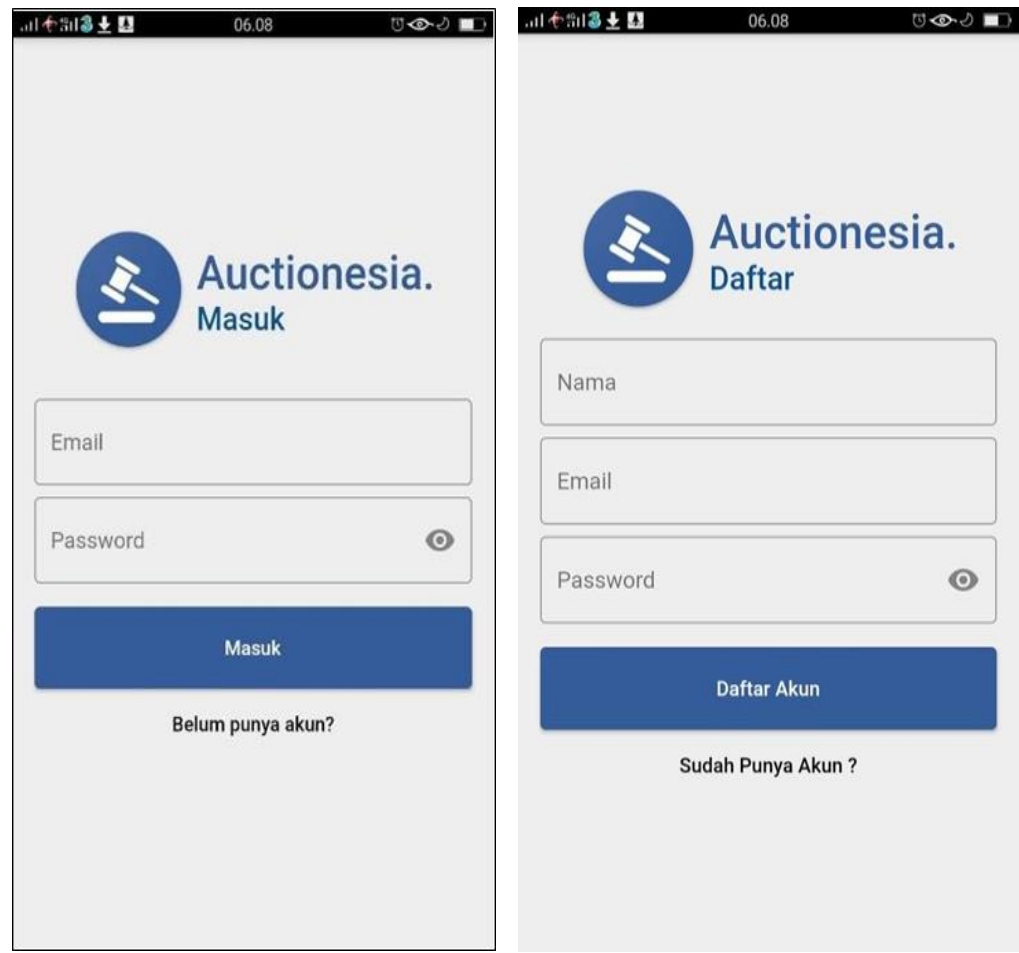

Gambar 4. Form Login dan Registrasi

Untuk melakukan atau mengikuti proses lelang pengguna dapat melihat pada halaman dashboard. Dimana pada halaman ini ditampilkan informasi lelang yang diberikan oleh pihak koperasi. Pada informasi lelang karet tersebut ditampilkan poto barang atau karet, lokasi karet, harga awal atau Tawaran terakhir dan waktu tersisa lelang. Informasi lelang tersebut seperti yang diperlihatkan pada Gambar 5. Peserta lelang juga dapat melakukan penawaran dengan cara mengklik lelang yang sedang berlangsung dan kemudia menaikkan harga dan mengklik kembali buat penawaran seperti yang diperlihatkan pada Gambar 5.
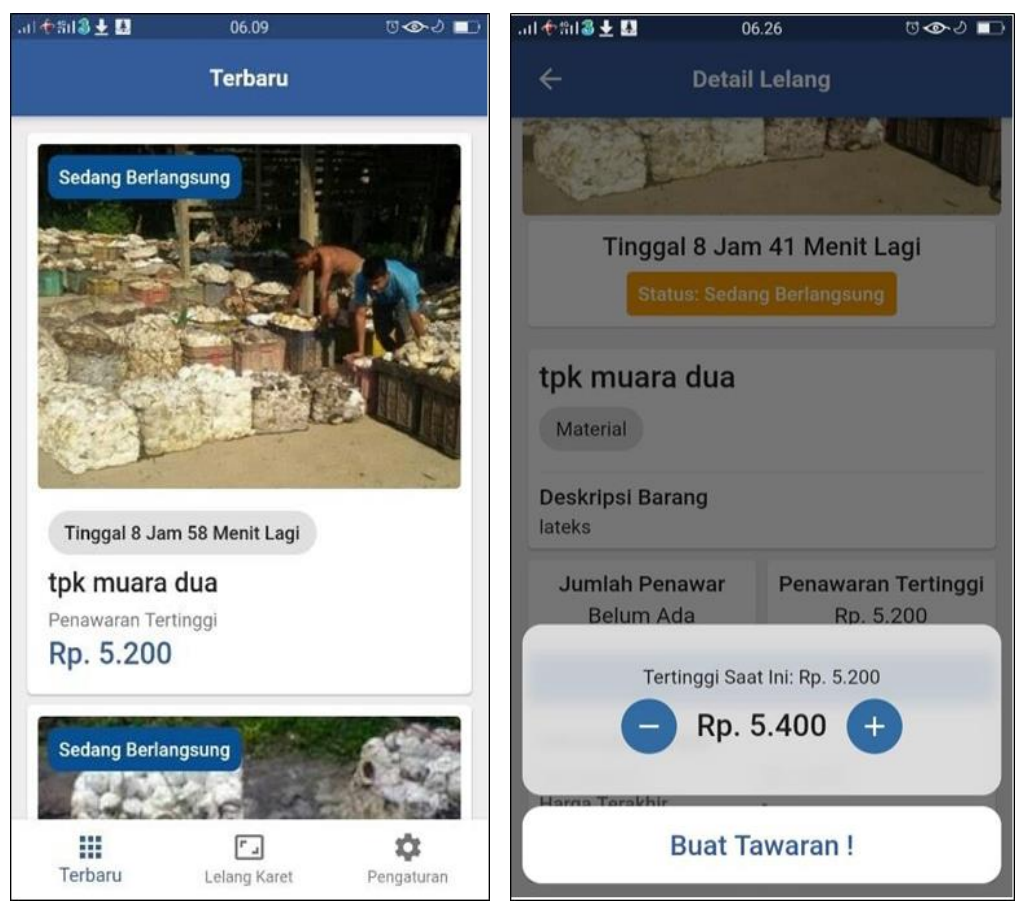

Gambar 5. Daftar Lelang 
Selanjutnya dari sisi pihak koperasi dapat melakukan penambahan data lelang abru dengan cara mengklik menu buat lelang, maka informasi lelang dapat ditambahkan dan akan ditampilkan pada halaman peserta lelang atau pabrik. Proses penambahan lelang baru seperti yang diperlihatkan pada Gambar 6.

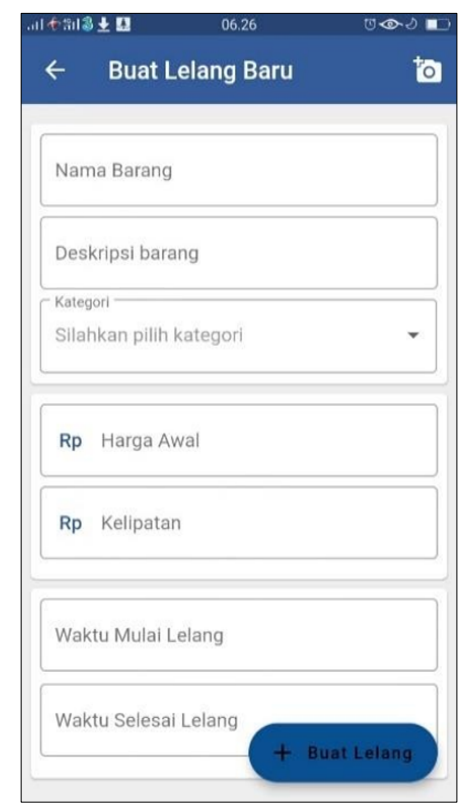

Gambar 6. Penambahan Lelang Baru

Dalam melakukan pengujian aplikasi lelang karet maka metode pengujian yang digunakan adalah black box testing. Dalam melakukan pengujian denan black box testing dilihat fungsional dari aplikasi apakah berjalan sesuai harapan atau sebaliknya. Dengan kata lain proses pengujian black box digunakan untuk melihat input dan output dari aplikasi apakah berjalan sesuai rencana yang diiningkan atau tidak (Ependi, 2017). Hasil pengujian aplikasi lelang karet seperti yang diperlihatkan pada tabel 1. Sesuai dengan tabel 1 maka dapat dikatakan bahwa aplikasi yang dihasilkan telah sesuai dengan fungsionalitas dan sesuai dengan keinginan yang dibuktikan dari hasil pengujian yang menyatakan berhasil.

\section{Pembahasan}

Sesuai dengan proses pengembangan aplikasi yaitu menggunakan adaptive software development (ASD). Dimana dalam proses pengembangan tersebut memiliki tiga tahapan pengembangan yaitu speculation, collaboration dan learning. Proses pengembangan sendiri dimulai dari pemantapan atau pemahaman dari visi dan misi dari objek dalam hal ini pihak koperasi. Dengan mengeahui bagaimana visi dan misi maka akan diketahui pula bagaimana kemauan atau kebutuhan yang diperlukan oleh koperasi terutama dalam proses lelang. setelah diketahui bagaimana kebutuhan yang diinginkan oleh pihak koperasi maka kebutuhan tersebut digambarkan dalam bentuk diagram yang dapat dipahami ketika akan dilakukan proses pengembangan. Notasi diagram yang digunakan adalah unified modelling language $(U M L)$. Notasi UML sendiri memiliki berbagai macam diagram namun yang biasa digunakan untuk menggambarkan bagaimana sebuah aplikasi dibentuk dan berinteraksi digunakan behaviour diagram dalam bentuk use case diagram dan interaction diagram dakan bentuk activity diagram. Untuk itu di dalam penelitian ini digunakan kedua jenis diagram tersebut untuk menggambarkan bagaimana aplikasi tersebut dibentuk.

Setelah proses pertam selesai dilakukan yaitu speculation maka selanjugnya menjalanka collaboration. Dimana dalam tahapan ini dilakukan proes pengembangan dengan 
melibatkan pihak terkait dalam hal ini pihak koperasi yang akan menggunakan aplikasi lelang. hasil dari proses pengembangan pada tahapan ini berupa aplikasi berbasis mobile dengan spesifikasi atau flatform android.

Tabel 1. Hasil Pengujian Aplikasi

\begin{tabular}{|c|c|c|c|c|}
\hline No & Komponen & Cara Penguji & Hasil diharapkan & Hasil \\
\hline 1. & Login & $\begin{array}{l}\text { Pengguna yaitu } \\
\text { peserta atau TPK } \\
\text { menginputkan } \\
\text { username password }\end{array}$ & $\begin{array}{l}\text { Menampilkan halaman } \\
\text { terbaru apliasi lelang }\end{array}$ & $\begin{array}{l}{[\sqrt{ }] \text { Berhasil }} \\
{[\text { ]Tidak }}\end{array}$ \\
\hline 2. & Daftar & $\begin{array}{l}\text { User menginputkan } \\
\text { nama, email dan } \\
\text { password }\end{array}$ & $\begin{array}{l}\text { Data tersimpan dan } \\
\text { dapat login }\end{array}$ & $\begin{array}{l}{[\sqrt{ }] \text { Berhasil }} \\
{[\text { ]Tidak }}\end{array}$ \\
\hline 3. & $\begin{array}{l}\text { Data } \\
\text { Lelang }\end{array}$ & $\begin{array}{l}\text { Menampilkan data } \\
\text { lelang }\end{array}$ & $\begin{array}{l}\text { Sistem menampilkan } \\
\text { data data lelang yang } \\
\text { terbaru sampai yang }\end{array}$ & $\begin{array}{l}{[\sqrt{ }] \text { Berhasil }} \\
{[\text { ]Tidak }}\end{array}$ \\
\hline 4. & Tawaran & $\begin{array}{l}\text { User mengiputkan } \\
\text { tawaran harga }\end{array}$ & $\begin{array}{l}\text { Sistem memproses } \\
\text { tawaran harga dan } \\
\text { menyimpan tawaran } \\
\text { harga yang dimasukan }\end{array}$ & $\begin{array}{l}{[\sqrt{ }] \text { Berhasil }} \\
{[\text { ]Tidak }}\end{array}$ \\
\hline 5. & $\begin{array}{l}\text { Tambah } \\
\text { Lelang }\end{array}$ & $\begin{array}{l}\text { User TPK } \\
\text { menambahkan } \\
\text { Tambah bahan } \\
\text { olahan karet }\end{array}$ & $\begin{array}{l}\text { Sistem meproses dan } \\
\text { menapilkan ke form } \\
\text { daftar lelang atau data } \\
\text { terbaru }\end{array}$ & $\begin{array}{l}{[\sqrt{ }] \text { Berhasil }} \\
{[\text { ]Tidak }}\end{array}$ \\
\hline
\end{tabular}

Aplikasi yang dihasilkan memiliki fitur mulai dari input barang lelang yang dilakukan oleh admin yang dalam hal ini pihak koperasi, pemberitahuan pihak terkait tentang barang lelang, melakukan penawaran barang lelang oleh perserta lelang, dan penentuan pihak pemenang lelang sesuai dengan tawaran harga dari peserta lelang. dimana semua proses tersebut tentunya dilakukan melalui aplikasi yang dihasilkan dari proeses collaboration.

Proses terakhir dari pengembangan aplikasi lelang dengen menggunakan adaptive software development (ASD) adalah learning. Proses ini merupakan proses pemastian apakah aplikasi yang dihasilkan telah memiliki fitur dengan fungsi yang diharapkan ataukah sebaliknya. Untuk itu dalam fase ini digunakan pengujian black box testing sebagai proses pemastian tersebut. Penggunaan black box testing sendiri disebabkan dalam proses pengujian dilakukan uji coba data dan juga melibat bagaimana input dan juga output (Anam \& Anwar, 2020). Untuk itu dapat diketahui bahwa sesuai dengan hasil pengujian menunjukkan semua fitur pada palikasi lelang karet berfungsi dengan baik yang dibukti dari semua komponen uji berhasil untuk melakukan proses data baik itu input maupun output seperti yang diperlihatkan pada tabel 1.

Dari kedua penelitian yang telah dilakukan Nopita (2018) dan Nuraminudin (2020) sebelumnya oleh terdapat perbedaan yang dilakukan dari penelitian ini diantaranya adalah: (1) aplikasi yang dihasilkan ini memiliki prosedur berupa data lelang yaitu hasil karet diberikan langsung oleh petani. (2) pihak pelelang dalam hal ini koperasi memberikan data lelang kepada peserta lelang melalui aplikasi berupa notifikasi. (3) peserta lelang dapat melakukan penawaran langsung terhadap hasil karet yang dilakukan lelang melalui aplikasi. (4) semua proses lelang dapat dilihat oleh pemilik barang dalam hal ini pemilik hasil karet yaitu petani. Sedangkan jika dilihat dari kedua aplikasi yang telah dihasilkan sebelumnya yaitu (1) pada aplikasi lelang barang jaminan, pada aplikasi atau penelitian tersebut dibuat 
searah dengan kata lain pihak perusahaan menawarkan barang kepada pihak mana saja dan pihak pemilik barang tidak dapat mengetahui harga barang yang ditawarkan walaupun aplikasi yang dikembangkan dibuat berbasis mobile. (2) pada aplikasi atau peneltian implementasi onesignal, dimana penelitian ini hanya menekankan pada proses notifikasi dan dikembangkan berbasis web. Selain itu juga peserta lelang juga bersifat umum dan proses bisnis yang dijalankan hampir sama dengan penelitian yang pertama.

\section{SIMPULAN}

Berdasarkan proses penelitian yang telah dilakukan maka dapat disimpulkan bebeara hal sebagai berikut yaitu: pengembangan aplikasi lelang karet telah dilakukan dengan mengimplementasikan metode adaptive software development dengan tiga tahapan utama speculation, collaboration, dan learning. Pemodelan informasi dilakukan mengunakan unified modelling language dengan dua jenis diagram yaitu behaviour diagram dan interaction diagram. Aplikasi yang dihasilkan dari proses pengembangan menunjukkan dapat melakukan lelang terutama kepada peserta lelang pabrik. Aplikasi yang dihasilkan dapat berfungsi dengan baik yang dibuktikan dengan hasil pengujian yang dilakukan terhadap aplikasi menggunakan teknik black box.

\section{REFERENSI}

Anam, M. K., \& Anwar, R. (2020). Penerapan Aplikasi Pendukung Touring Pada Komunitas Motor Berbasis Android. Edumatic: Jurnal Pendidikan Informatika, 4(1), 1-10.

Andri, \& Suyanto. (2020). Sistem Informasi Penentuan Guru Terbaik Berbasis Kinerja pada Pondok Pesantren Qodratullah. Digital Zone: Jurnal Teknologi Informasi Dan Komunikasi, 11(1), 108-119.

Basry, A., \& Sari, E. M. (2018). Penggunaan Teknologi Informasi Dan Komunikasi (Tik) Pada Usaha Mikro, Kecil Dan Menengah (UMKM). IKRA-ITH Informatika: Jurnal Komputer Dan Informatika, 2(3), 53-60.

Elvaricha, W. C. (2019). Implementasi metode Adaptive Software Development pada sistem penentuan UKT (Uang Kuliah Tunggal) di UIN Maulana Malik Ibrahim Malang. Skripsi. Universitas Islam Negeri Maulana Malik Ibrahim.

Ependi, U. (2017). Uji Coba Dan Implementasi Test Engine System Bina Darma Career And Training Center. Jurnal Sistem Informasi (JSI), 9(1), 1222-1232.

Ependi, U. (2018). Pemodelan Sistem Informasi Monitoring Inventory Sekretariat Daerah Kabupaten Musi Banyuasin. Klik-Kumpulan Jurnal Ilmu Komputer, 5(1), 49-60.

Ependi, U., Panjaitan, F., \& Syakti, F. (2020). Pengembangan Aplikasi Mobile Travel Guide pada Provinsi Sumatera Selatan. Jurnal Teknologi Informasi Dan Ilmu Komputer, 7(3), 607-618.

Fatmasari, F., \& Sauda, S. (2020). Pemodelan Unified Modeling Language Sistem Informasi Enterprise Resource Planning. Jurnal Media Informatika Budidarma, 4(2), 429-436.

Fatoni, A., \& Dwi, D. (2016). Rancang bangun sistem extreme programming sebagai metodologi pengembangan sistem. PROSISKO: Jurnal Pengembangan Riset Dan Observasi Sistem Komputer, 3(1), 17-20.

Hayat, A., Prastica, T., Susanti, S., \& Isyamarwati, A. (2015). Prototipe Sistem Informasi Persediaan Barang Logistik Berbasis Web Dengan Pemodelan UML. Proceedings Konferensi Nasional Sistem Dan Informatika (KNS\&I), 373-378. Bali: STMIK STIKOM Bali

Nopita, P. (2018). Aplikasi Lelang Barang Jaminan Berbasis Android pada PT. Pegadaian (Persero) UPC Sei. Jering. Jurnal Perencanaan, Sains Dan Teknologi (JUPERSATEK), $1(2), 228-235$.

Nugroho, K. (2018). Perancangan UML Sistem Digital Archives Proposal Dan Tugas Akhir 
Mahasiswa Dengan Cloud Computing. Seminar Nasional Multi Disiplin Ilmu, 178-184. Semarang: UNISBANK

Nuraminudin, M. (2020). Analisis Dan Implementasi Onesignal Dalam Pembuatan Aplikasi Mobile Hybrid Lelang Ikan Hias. JURTEKSI (Jurnal Teknologi Dan Sistem Informasi), 6(3), 209-214.

Rahma, F. (2018). Rancang Bangun Sistem Informasi Koperasi Simpan Pinjam Pembiayaan Syariah Berbasis Kelompok. Jurnal Nasional Teknologi Dan Sistem Informasi, 4(1), 920.

Sagala, J. R. (2014). Implementasi Sistem Aplikasi Belajar Rumus Matematika Metode Adaptive Software Development Pada Smp Swasta Methodist 7 Medan. Jurnal Mantik Penusa, 15(1), 8-15.

Sasmita, G. M. A., \& Jasa, L. (2011). Rancang Bangun Sistem Lelang On-Line Pegadaian. LONTAR KOMPUTER, 2(1), 42-51.

Surjono, H. D. (2013). Peranan teknologi informasi dan komunikasi (ICT) dalam peningkatan proses pembelajaran yang inovatif. Seminar Nasional Pendidikan \& Saintec, 18, 1-10. Yogyakarta: Universitas Negeri Yogyakarta

Suyanto, S., \& Andri, A. (2020). Pengembangan Aplikasi Pencarian Klinik Dengan Algoritma Bellman Ford. Jusikom: Jurnal Sistem Komputer Musirawas, 5(1), 70-81.

Tujni, B., \& Hutrianto, H. (2020). Pengembangan Perangkat Lunak Monitoring Wellies Dengan Metode Waterfall Model. Jurnal Ilmiah Matrik, 22(1), 122-130.

Wulan, R. (2016). Pengembangan Konfigurasi Model Analisis Arsitektur Agile Pada Perusahaan Bisnis It Online (Studi kasus Lazada dan Bhineka. com). Faktor Exacta, 9(2), 166-177. 